\title{
Preliminary Results from Exploratory Sampling of Wells for the California Oil, Gas, and Groundwater Program, 2014-15
}

By Peter B. McMahon, Justin T. Kulongoski, Michael T. Wright, Michael T. Land, Matthew K. Landon, Isabelle M. Cozzarelli, Avner Vengosh', and George R. Aiken

\section{Introduction}

In 2014 and 2015, the U.S. Geological Survey (USGS) sampled water wells in the Los Angeles Basin and southern San Joaquin Valley, California, and oil wells in the San Joaquin Valley for analysis of multiple chemical, isotopic, and groundwater-age tracers (fig. 1). The purpose of this reconnaissance sampling was to evaluate the utility of tracers for assessing the effects of oil and gas production activities on groundwater quality in California. The

${ }^{1}$ Duke University study was done in cooperation with the California State Water Resources Control Board. Results of the study are intended to help design a regional groundwatermonitoring program to be implemented as part of California Senate Bill 4 (SB 4 statutes of 2013). The regional monitoring program plans to assess the effects of oil and gas production activities on groundwater quality and to provide a regional context for local monitoring of the groundwater-quality effects from well-stimulation treatments, which are techniques used to improve oil and gas production by increasing their rate of flow to the well. California SB 4 mandates that this local monitoring is to be done by oil-well operators in accordance with monitoring criteria established by the State Water Board.

This report evaluates the utility of the chemical, isotopic, and groundwater-age tracers for assessing sources of salinity, methane, and petroleum hydrocarbons in groundwater overlying or near several California oil fields. Tracers of dissolved organic carbon in oil-field-formation water are also discussed. Tracer data for samples collected from 51 water wells and 4 oil wells are examined.
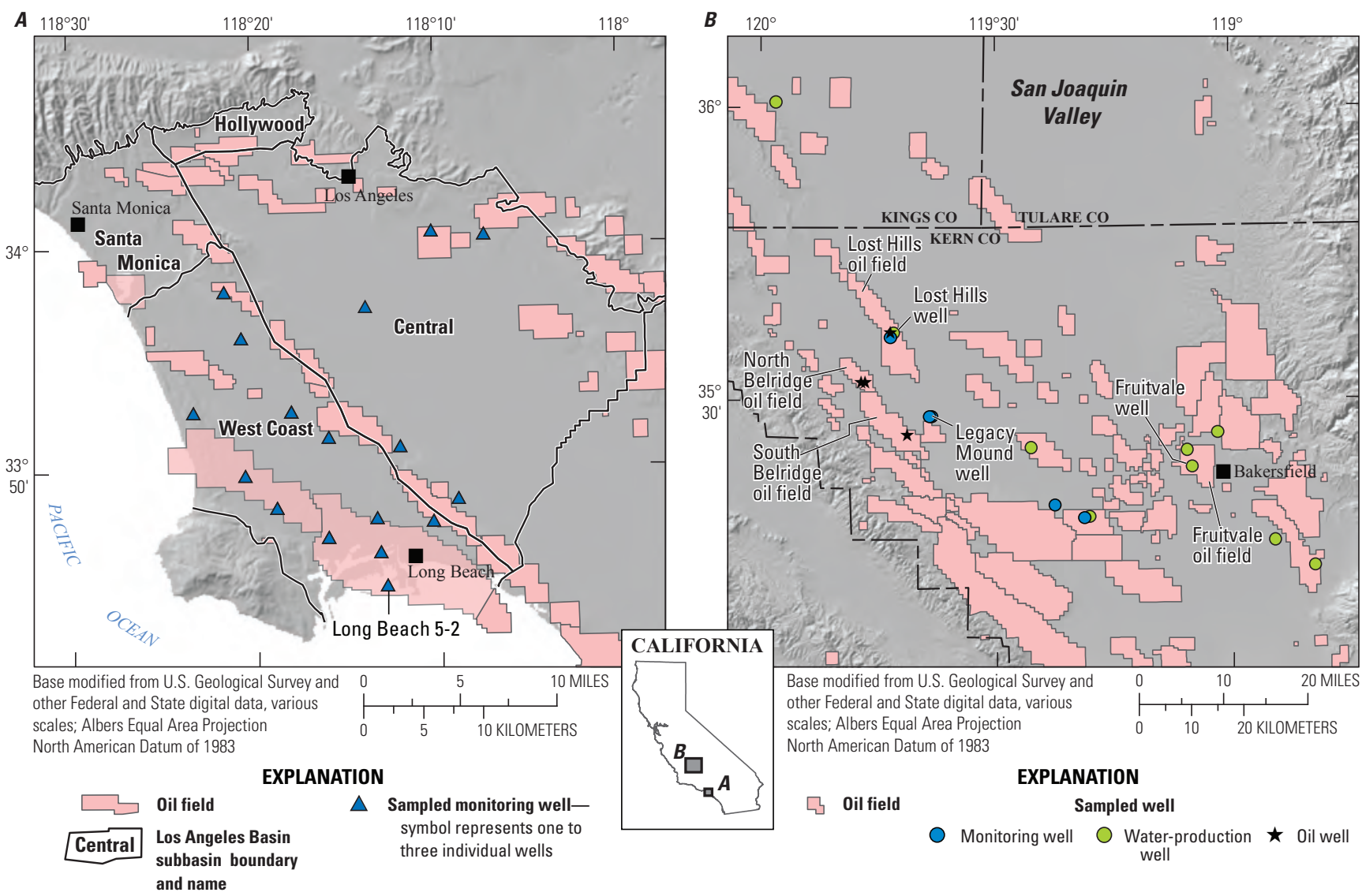

Figure 1. The locations of wells sampled in selected oil and gas production areas in California from 2014 to 2015 in the $A$, Los Angeles Basin, and $B$, southern San Joaquin Valley. 


\section{Sample Collection and Analysis}

In the Los Angeles Basin, groundwater samples were collected from 37 short-screened USGS monitoring wells at 17 multi-well monitoring sites overlying or near oil fields (fig. $1 A$ ). The depth to the bottom of open intervals in the monitoring wells ranged from 91 to 607 meters $(\mathrm{m})$, whereas, in nearby oil fields, the top of open intervals in active oil and gas production wells was below that of the deepest water well (Tracy Davis, U.S. Geological Survey, written commun., April 2016). In the southern San Joaquin Valley, groundwater samples were collected from 14 monitoring and water-production wells overlying or near oil fields in Kern and Kings Counties, and samples of "produced water" (that is, water brought to the surface by oil and gas production wells) were collected from four oil wells in three oil fields in Kern County, along the west side of the valley (fig. 1B). The depths to the bottom of open intervals in the monitoring and water production wells ranged from 91 to $296 \mathrm{~m}$, and, in nearby oil fields, the depth to the top of open intervals in active oil and gas production wells was in the same range or deeper than that of the water wells (Tracy Davis, U.S. Geological Survey, written commun., April 2016).

Groundwater samples were analyzed for field parameters; major, minor, and trace elements; nutrients; volatile and semi-volatile organic compounds; concentrations and optical properties of dissolved organic carbon; hydrogen and oxygen isotopic composition of the water; isotopic composition (hydrogen, oxygen, carbon, strontium, boron) of various dissolved inorganic constituents; radium-226 and radium-228; groundwater-age tracers (tritium, helium-3, carbon-14); noble gases; chemical composition of hydrocarbon gases (methane through hexane); and the hydrogen and carbon isotopic composition of methane. Produced water samples were analyzed for many of the same constituents. It was important to evaluate a suite of tracers having a broad range of physical and chemical properties because the types of chemicals associated with oil and gas production activities and their transport pathways can be complex. Methods of sample collection and analysis for groundwater are described by Dillon and others (2016). Samples of produced water were collected at the well head of oil wells by using methods described by Engle and others (2016). For the produced-water data presented in this report, methods for field processing of samples and laboratory analyses were similar to those used for groundwater samples, except that major ions and trace elements in produced water were analyzed by the USGS laboratory in Reston, Virginia, rather than the USGS National Water-Quality Laboratory in Lakewood, Colorado. Groundwater data presented in this report are tabulated in Dillon and others (2016), and produced-water data are tabulated in Davis and others (2016).

\section{Tracers of Salinity in Groundwater}

Hydrocarbon-bearing geologic formations (oil-field formations) commonly contain saline water, which could degrade the quality of fresh groundwater, if the two water types mixed. Mixing could result from natural hydrologic processes (Warner and others, 2012) or from oil and gas production activities (Thamke and Smith, 2014). In some cases, it is necessary to distinguish water from oil-field formations from other sources of saline water, such as seawater or other natural brines. Stable isotopes of water, concentrations of dissolved chloride, and other chemical and isotopic tracers can help identify sources of saline water that mix with groundwater.

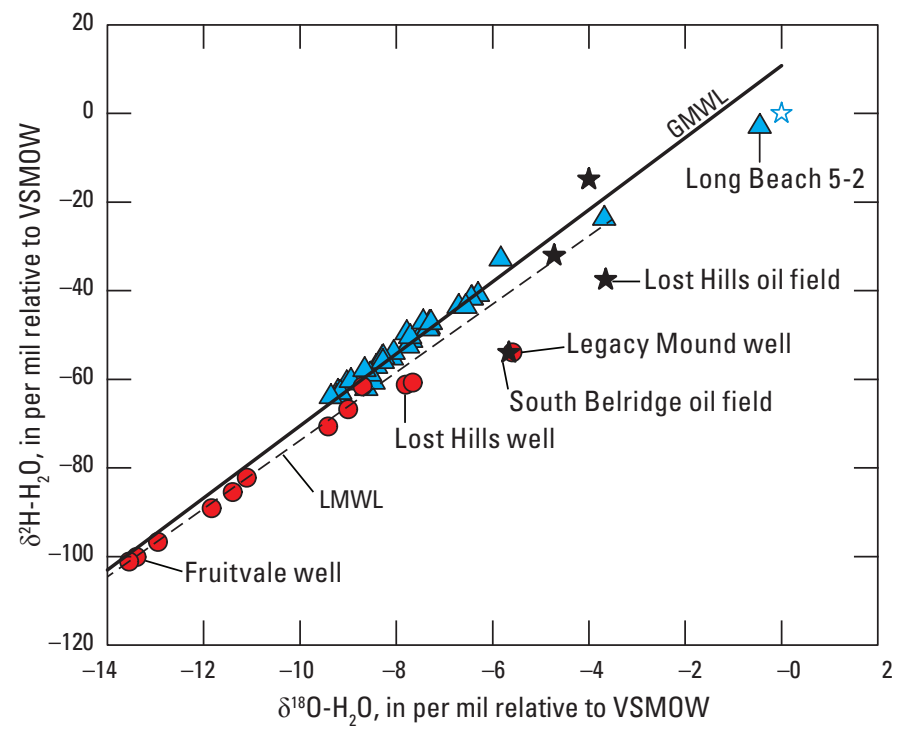

EXPLANATION

\begin{tabular}{cc}
$\triangle$ Los Angeles Basin & \multicolumn{2}{c}{ Southern San Joaquin Valley } \\
Groundwater & $\quad$ Groundwater \\
Seawater & $\star$ Produced water
\end{tabular}

Figure 2. The hydrogen $\left(\delta^{2} \mathrm{H}-\mathrm{H}_{2} \mathrm{O}\right)$ and oxygen $\left(\delta^{18} \mathrm{O}-\mathrm{H}_{2} \mathrm{O}\right)$ isotopic composition of groundwater and produced water, collected for the exploratory sampling study in California, 2014-15, plotted relative to the Global Meteoric Water Line (GMWL) and Local Meteoric Water Line (LMWL) for Kern County. Isotopic values are reported relative to Vienna Standard Mean Ocean Water (VSMOW). 
The highest TDS concentration $(11,791 \mathrm{mg} / \mathrm{L})$ in groundwater samples from the southern San Joaquin Valley was from a well near the South Belridge oil field (Legacy Mound well in figures $1 B$ and 2). The isotopic composition of this groundwater sample plotted off the LMWL and was similar to that of the produced-water sample from the South Belridge oil field (fig. 2), indicating the sample contained a large fraction of oilfield-formation water. The Legacy Mound well was in an area east of the South Belridge oil field where produced-water disposal ponds were operated. A second groundwater sample containing a high concentration of TDS $(5,853 \mathrm{mg} / \mathrm{L})$, from a well in the Lost Hills oil field (Lost Hills well in figures $1 B$ and 2), also had an isotopic composition that plotted off the LMWL in the direction of some of the produced-water samples, including the sample from the Lost Hills oil field. The sample from the Lost Hills well appeared to contain less oil-field-formation water than the Legacy Mound sample, based on its plotted position in figure 2 relative to the LMWL and to the produced-water samples.

Plots of chloride concentrations relative to chloride/bromide mass ratios (fig. 3A), strontium concentrations relative to strontium-87/strontium-86 isotopic ratios (fig. $3 B$ ), and chloride concentrations relative to boron and sodium concentrations (figs. $4 A, B$ ) indicate that mixing of oil-field-formation water with groundwater contributed a variety of salts to the Legacy Mound and Lost Hills samples. The relative fractions of oil-field-formation water in the Legacy
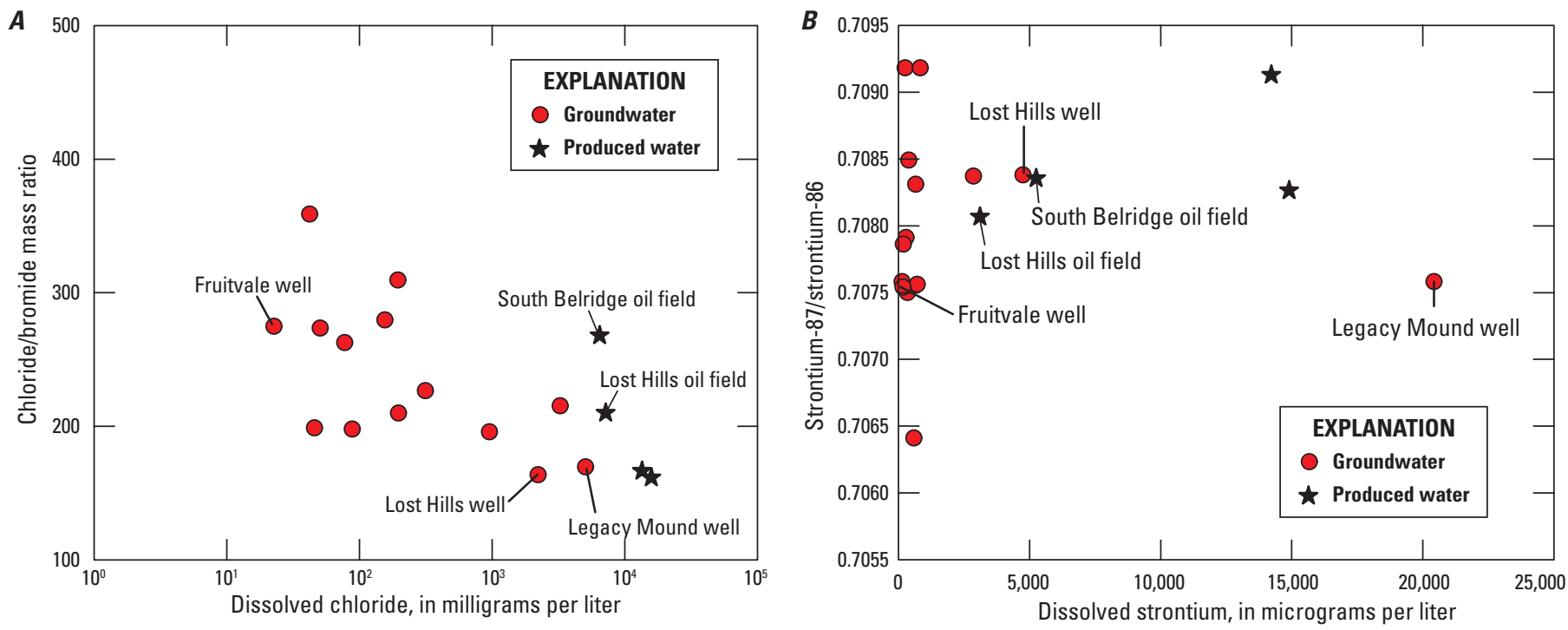

Figure 3. Concentrations of dissolved constituents in groundwater and produced water collected in the southern San Joaquin Valley, California, for the exploratory sampling study, 2014-15: $A$, chloride in relation to chloride/bromide mass ratios; and $B$, strontium in relation to strontium-87/strontium-86 isotopic ratios.
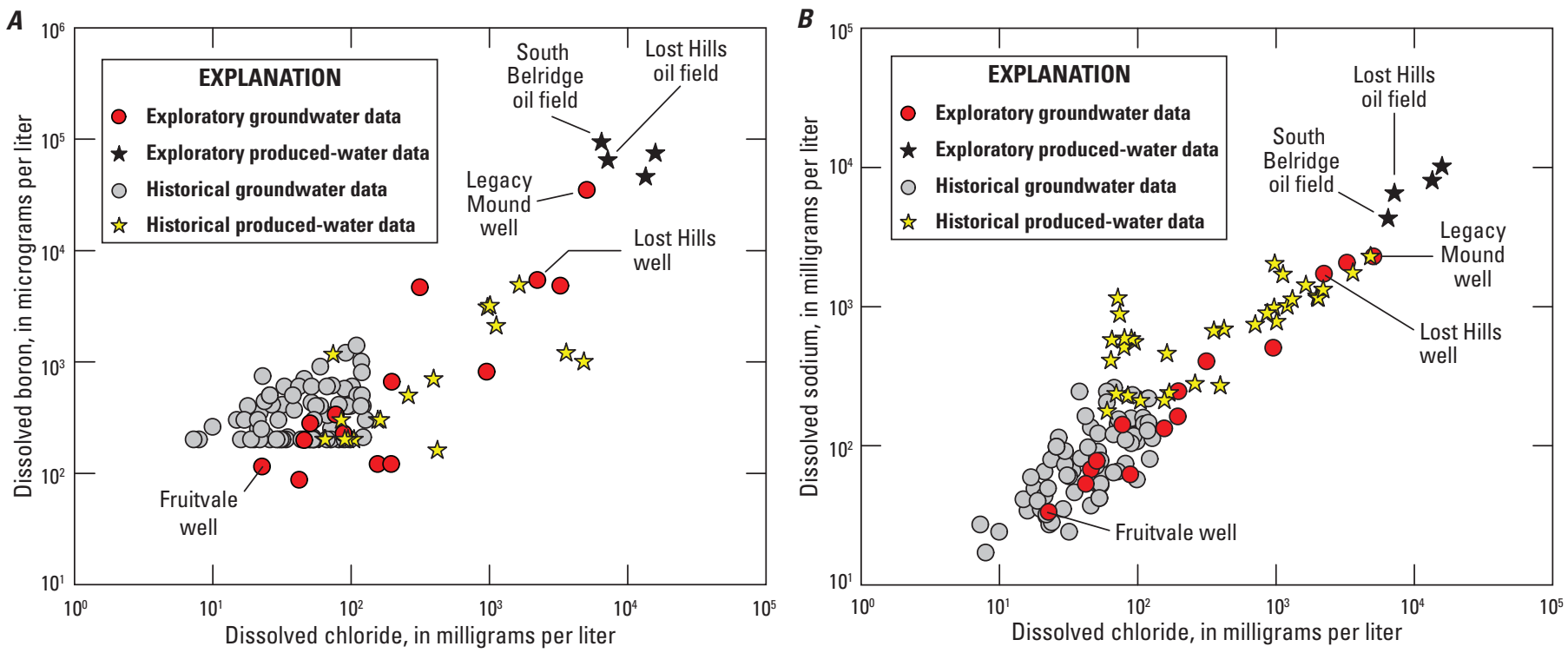

Figure 4. Concentrations of dissolved chloride in groundwater and produced water collected in the southern San Joaquin Valley, California, for the exploratory sampling study during 2014-15 and historical data for groundwater and produced water from the Fruitvale oil field in Kern County in relation to $A$, dissolved boron; and $B$, dissolved sodium. Historical data for the Fruitvale oil field are from the California Department of Oil, Gas, and Geothermal Resources (2014); Blondes and others (2014); U.S. Geological Survey (2016); California Department of Water Resources (2015); and California State Water Resources Control Board (2015). 
Mound and Lost Hills samples indicated by the chemical data in figures 3 and 4 were in general agreement with the fractions indicated by the isotopic data in figure 2, although inconsistencies in figure 3 compared to figures 2 and 4 indicate it is not clear which produced-water samples represent the end members for oil-field-formation water involved in the mixing process. The uncertainty in endmember compositions is probably due to variability in the composition of oil-fieldformation water in the study area that was not captured by the few produced-water samples collected for this study.

Boron, chloride, and sodium concentrations in produced water collected from the west side of the southern San Joaquin Valley for this study compared with historical produced-water data from the Fruitvale oil field on the east side of the valley showed there can be substantial differences in the chemistry of produced water across the valley and in an oil field (figs. $1 B$ and 4 ). The data in figure 4 show that the four samples of produced water collected for this study did not capture the range in variability of produced-water chemistry in and between oil fields in the valley. Thorough chemical characterization of produced water is important for understanding where and how oil-field-formation water mixes with groundwater; therefore, the regional monitoring program plans to include a more thorough characterization of the spatial variability in the chemistry of produced water in and among California oil fields.

\section{Tracers of Methane in Groundwater}

Methane in groundwater can be produced in aquifers or can originate from underlying oil-field formations. Understanding the sources of methane in groundwater can help identify connections between aquifers and oil-field formations. Concentrations of methane in groundwater ranged from less than 0.001 to $150 \mathrm{mg} / \mathrm{L}$ in the Los Angeles Basin samples and from less than 0.001 to $46 \mathrm{mg} / \mathrm{L}$ in the southern San Joaquin Valley samples (fig. 5A). The hydrogen and carbon isotopic composition of methane and chemical composition of hydrocarbon gas (methane through hexane) were used to distinguish between methane from biogenic and thermogenic origins. Biogenic methane is produced by methanogenic microorganisms at relatively low temperatures in aquifers, and thermogenic methane is produced by abiotic processes at relatively high temperatures in more deeply buried geologic formations (Schoell, 1980; Whiticar, 1999). Thermogenic methane is commonly associated with oil and gas deposits (fig. 5; Schoell, 1980). Methane in the Los Angeles Basin samples was predominantly biogenic and produced through the carbon-dioxide reduction pathway, one of two common metabolic pathways used by methanogens to produce methane (fig. $5 B$; Whiticar and others, 1986). These data, together with results from previous studies showing that oilassociated methane in the Los Angeles Basin is generally thermogenic in origin (Jeffrey and others, 1991), indicate that the methane in the Los Angeles Basin groundwater samples was not related to methane from deeper oil-field formations.

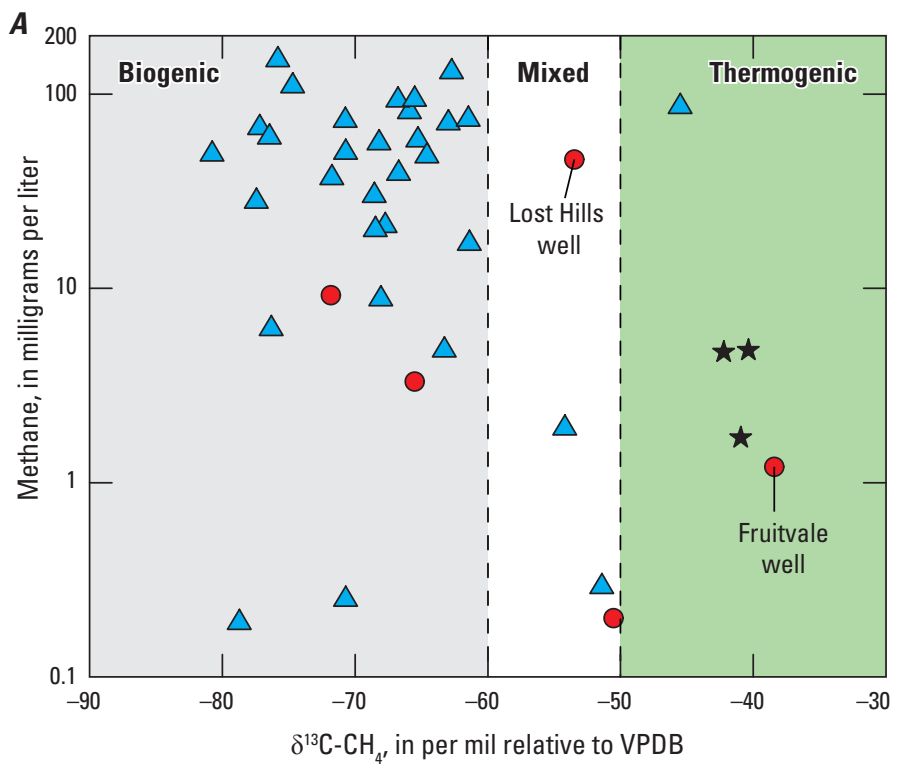

EXPLANATION

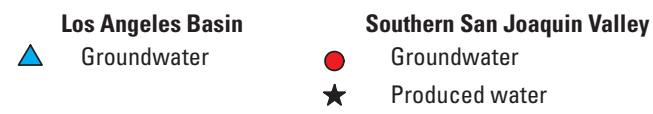

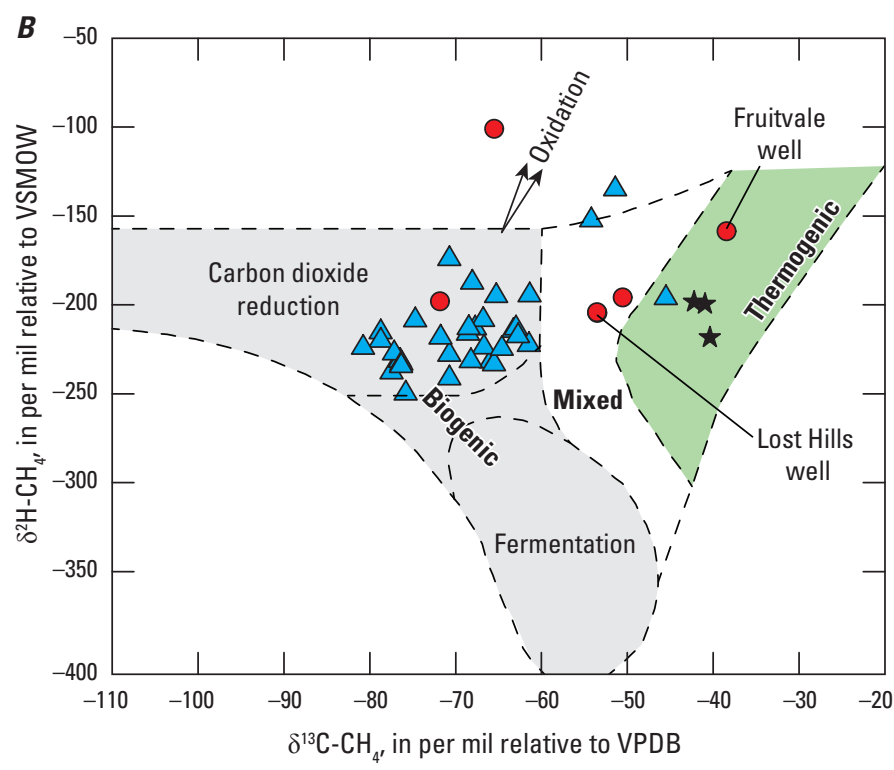

EXPLANATION

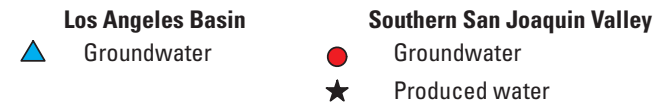

Figure 5. The carbon isotopic composition of methane $\left(\delta^{13} \mathrm{C}-\mathrm{CH}_{4}\right)$ in groundwater and produced water collected for the exploratory sampling study during 2014-15 in relation to $A$, methane concentration; and $B$, the hydrogen isotopic $\left.\operatorname{composition}^{2} \delta^{2} \mathrm{H}-\mathrm{CH}_{4}\right)$ of methane. $Z$ one boundaries for biogenic and thermogenic methane are from Whiticar and others (1986), and oxidation trends in $B$ are from Coleman and others (1981) and Martens and others (1999). Samples with methane concentrations less than 0.1 milligram per liter are not shown because there was insufficient methane in those samples to measure methane isotopes. Isotopic values are reported relative to Vienna Standard Mean 0 cean Water (VSMOW) for hydrogen and Vienna Peedee Belemnite (VPDB) for carbon. 
In contrast to the Los Angeles Basin samples, some groundwater samples from the southern San Joaquin Valley appeared to contain thermogenic methane. The sample from the Lost Hills well had a methane isotope value between those typical of biogenic and thermogenic methane (fig. 5), indicating it contained methane from both sources. This interpretation is consistent with other chemical and isotopic data indicating water from that well was a mixture of groundwater and oil-field-formation water (figs. 2-4). The presence of propane, butane, and pentane in the Lost Hills sample (Dillon and others, 2016) further supports the interpretation that thermogenic gas was present in that sample (Jackson and others, 2013). A sample from a water-production well in the Fruitvale oil field (Fruitvale well in figs. $1 B$ and 5) contained $1.2 \mathrm{mg} / \mathrm{L}$ of methane that appeared to be entirely thermogenic in origin based on its methane isotope composition (figs. $1 B$ and 5). The sample also contained propane and butane. Boron, chloride, and sodium data from the Fruitvale well and historical data for groundwater and produced water in the Fruitvale oil field indicated water from that well contained relatively little, if any, oil-field-formation water (fig. 4), indicating the transport of thermogenic methane gas to that well may have been decoupled from the movement of oilfield-formation water.

Water from the Legacy Mound well contained less than $0.05 \mathrm{mg} / \mathrm{L}$ methane, which was too little for isotopic analysis, even though chemical and isotopic data indicated the sample contained the largest fraction of oil-field-formation water of all the water wells sampled in the southern San Joaquin Valley (figs. 2-4). If groundwater reaching the Legacy Mound well was recharged from disposal ponds at the land surface, then the lack of methane in that sample could be a result of methane degassing to the atmosphere or, possibly, methane oxidation in the ponds prior to water recharging the aquifer.

A variety of subsurface processes can alter methane isotopes from their initial or expected values, which can complicate the use of isotopes to trace methane sources. Methane oxidation, for example, could shift the isotopic composition of biogenic methane away from the biogenic field in figure $5 \mathrm{~B}$. Additional tracers can sometimes be useful for recognizing those processes. For example, at least one sample from the southern San Joaquin Valley appeared to have been affected by methane oxidation on the basis of the relatively enriched $\delta^{2} \mathrm{H}$ value of -101.2 per mil for methane (fig. $5 B$ ) and the depleted $\delta^{13} \mathrm{C}$ value of -45.4 per mil for dissolved inorganic carbon (DIC; Dillon and others, 2016), both of which are characteristic effects of methane oxidation (Whiticar, 1999; Avrahamov and others, 2015). One sample from the Los Angeles Basin had a relatively enriched $\delta^{13} \mathrm{C}$ value for methane compared to most other samples from that area, and it plots in the thermogenic field in figure 5. The $\delta^{13} \mathrm{C}$ value for DIC in the sample was also enriched at +12.4 per mil (Dillon and others, 2016). Enrichment of ${ }^{13} \mathrm{C}$ both in methane and DIC are characteristic effects of substrate depletion during the later stages of methane production through the carbon-dioxide reduction pathway (Avrahamov and others, 2015), indicating methane in the sample could be biogenic in origin. Furthermore, unlike the samples from the Lost Hills and Fruitvale wells that contained thermogenic methane, that Los Angeles Basin sample did not contain hydrocarbons, such as propane and butane, that are common in thermogenic gas.

Data from the Legacy Mound, Lost Hills, and Fruitvale wells illustrated the value of collecting multiple tracers to understand sources, movement, and fate of chemicals in groundwater in the vicinity of California oil fields. Tracer data indicated that salts and gas from oil-field formations both entered the aquifer near the Lost Hills well. At the Legacy Mound well, the data indicated only salts (no gas) from oil-field formations moved into the aquifer, consistent with a history of the disposal of oil-field produced water near this site. Finally, at the Fruitvale well, the data appeared to indicate that only gas (no salts) from oil-field formations moved into the aquifer. Understanding chemical transport pathways at each of those locations was beyond the scope of the exploratory study, but is important to the understanding of connections between aquifers and oil-field formations. Study of these transport pathways is a component of the regional monitoring program.

\section{Tracers of Petroleum Hydrocarbons in Groundwater}

Petroleum hydrocarbons in groundwater could have sources in the subsurface and at the land surface. Natural fluid migration from oil-field formations and leakage of fluids through fractured casings or cement seals in wells for oil and gas production are examples of hydrocarbon sources in the subsurface. Produced-water disposal ponds and leaking storage tanks and pipelines are examples of hydrocarbon sources at the land surface. The exploratory data provide examples of how patterns of association between petroleum hydrocarbons, volatile organic compounds (VOCs) manufactured for industrial and other uses, and groundwater-age tracers can be used to gain a better understanding of the sources of hydrocarbons detected in groundwater. Analysis of hydrocarbon associations is facilitated by the low detection levels used for VOC analyses in the exploratory study-less than 0.1 microgram per liter $(\mu \mathrm{g} / \mathrm{L})$ for most VOCs, rather than detection levels of $0.5 \mu \mathrm{g} / \mathrm{L}$ or greater typically used for regulatory programs.

Tritium and carbon- 14 concentrations in the groundwater samples were used to group the samples into three general age categories (fig. 6). In figure 6, the area of "modern" water is defined by tritium concentrations greater than 1 tritium unit (TU) and carbon-14 concentrations greater than 90 percent modern carbon (pmc) on the basis of work done in the Central Valley by Jurgens and others (2010). Samples that plot in the modern field in figure 6 are generally considered to represent groundwater that recharged since the early 1950s (Jurgens and others, 2010). The area of "pre-modern" water is defined by tritium concentrations less than 0.1 TU and carbon-14 concentrations less than 80 pmc. Groundwater that recharged aquifers in the study areas before the early 1950 s probably contained about 3 to 4 TU of tritium at the time of recharge (Michel, 1989), but it would contain less than 0.1 TU of tritium at the time of sampling in 2014 and 2015 because of radioactive decay of the tritium. The 80-pmc boundary represents the highest carbon-14 concentration in samples that contained less than 0.1 TU of tritium. Samples that plot in the premodern field are generally considered to represent groundwater that recharged 


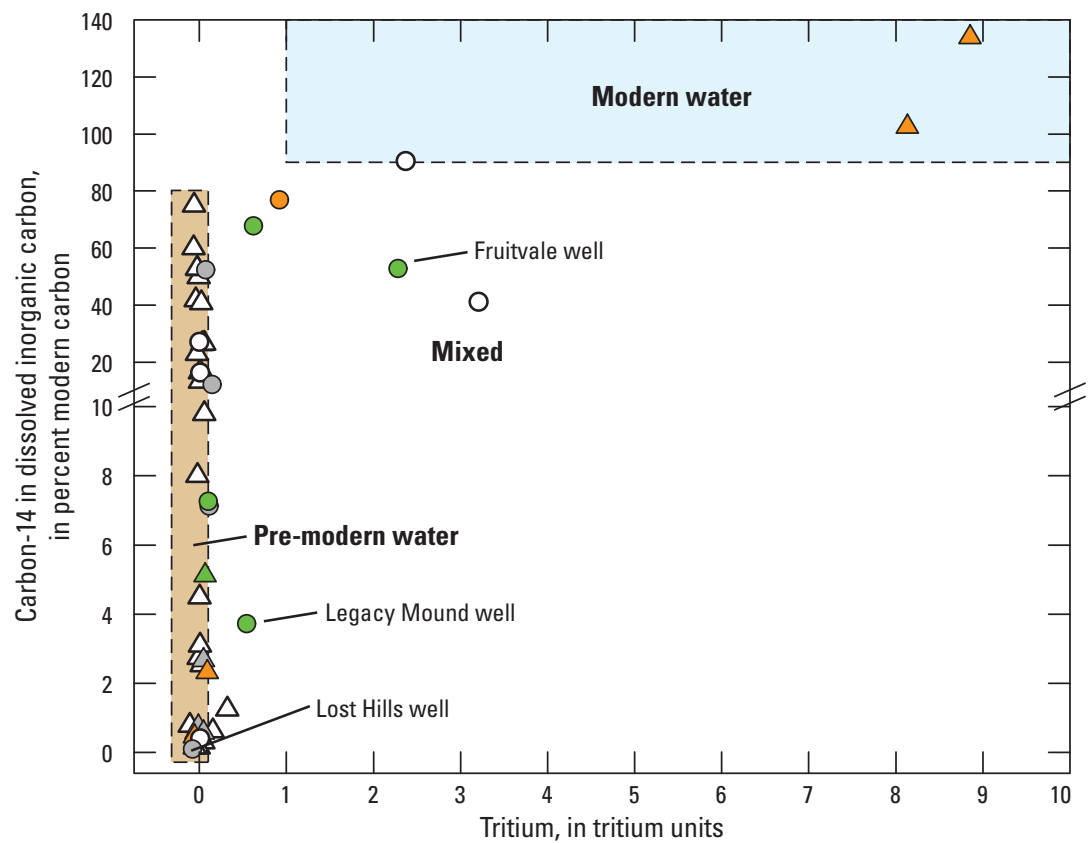

EXPLANATION

Volatile organic compound detections

\begin{tabular}{rcccc} 
& \multicolumn{2}{c}{ Volatile organic compound detections } \\
$\begin{array}{r}\text { Not } \\
\text { Groundwater }\end{array}$ & $\begin{array}{c}\text { Petroleum } \\
\text { detected } \\
\text { hydrocarbons } \\
\text { hos Angeles Basin }\end{array}$ & $\Delta$ & $\Delta$ & $\begin{array}{c}\text { Manufactured } \\
\text { compounds } \\
\text { manufactured } \\
\text { compounds }\end{array}$ \\
Southern & $\circ$ & 0 & $\Delta$ & $\Delta$ \\
San Joaquin Valley & 0 & & 0 & 0
\end{tabular}

Figure 6. Tritium concentrations in relation to carbon-14 concentrations in groundwater collected for the exploratory sampling study during 2014-15.

before the early 1950s. Samples in the pre-modern field that had the lowest carbon- 14 concentrations could be many thousands of years old. Samples that plot in the "mixed" area contain fractions of both modern and pre-modern water.

Petroleum hydrocarbons were detected in eight groundwater samples from the southern San Joaquin Valley (Dillon and others, 2016). Four of the eight samples contained groundwater that was mostly recharged prior to the early 1950s and no manufactured VOCs (fig. 6). Two of these relatively old groundwater samples, including the sample from the Lost Hills well, contained concentrations of benzene greater than the California maximum contaminant level for drinking water of $1 \mu \mathrm{g} / \mathrm{L}$ (California State Water Resources Control Board, 2016) as well as seven to ten associated hydrocarbons (including ethylbenzene, xylenes, and trimethylbenzenes; Dillon and others, 2016), which is consistent with a subsurface source of petroleum hydrocarbons in the groundwater samples unrelated to sources at the land surface (Landon and Belitz, 2012).

Manufactured VOCs and at least some groundwater recharged after the early 1950 s were detected in the other four samples in which hydrocarbons were detected (fig. 6), including the samples from the Legacy Mound and Fruitvale wells. The Legacy Mound sample contained a suite of hydrocarbons similar to those detected in the Lost Hills sample, including benzene, but it also contained dichlorobenzenes and 1,2-dichloropropane. The hydrocarbons detected in the Legacy Mound sample were consistent with a history of disposal of oil-field produced water near the site. It is not known if the produced-water disposal ponds were the primary source of the manufactured VOCs and modern water detected in the sample, but they are evidence of a connection between the Legacy Mound well and human activities at the land surface. The Fruitvale sample appeared to contain little if any oil-field-formation water based on the isotopic and inorganic chemical data (figs. 2-4), and it contained more manufactured VOCs-including tetrachloroethene [PCE], trichloroethene [TCE], and cis-1,2-dichloroethene [cis-DCE] — and probably a larger fraction of modern water than the Legacy Mound sample (fig. 6). These patterns could be consistent with hydrocarbons in the Fruitvale well having a source at the land surface unrelated to produced water.

Petroleum hydrocarbons were detected in four groundwater samples from the Los Angeles Basin (Dillon and others, 2016). All four samples contained groundwater that was mostly recharged prior to the early 1950s and, possibly, hundreds or thousands of years ago on the basis of tritium and carbon-14 data (fig. 6). Two of the samples contained benzene at low concentrations (less than $0.03 \mu \mathrm{g} / \mathrm{L}$ ) that was not associated with manufactured VOCs, indicating a subsurface source of petroleum hydrocarbons unrelated to sources at the land surface (Landon and Belitz, 2012). One sample of apparently old groundwater contained the manufactured VOCs 1,1-dichloroethene and cis-DCE at concentrations less than $0.05 \mu \mathrm{g} / \mathrm{L}$.

Low concentrations of manufactured VOCs, particularly chlorinated solvents, in some samples of seemingly old groundwater (tritium less than $0.1 \mathrm{TU}$ and carbon-14 less than $10 \mathrm{pmc}$ ) could indicate mixing between old, VOC-free groundwater and younger groundwater containing VOCs. Many of the manufactured VOCs detected in seemingly old groundwater were in use before the early 1950s (Zogorski and others, 2006), so the young end member in the mixture could have been relatively young pre-modern groundwater or modern groundwater (fig. 6). Either of these young end members could mix with old groundwater to produce a mixture containing low concentrations of tritium, carbon-14, and VOCs. The fraction of young water, and its VOC concentration, required to produce the observed mixtures would depend on factors such as the concentrations of tritium, carbon-14, and alkalinity in the young and old end members. The exploratory study did not analyze produced water for VOCs, so it is not known if produced water in California oil fields contains chlorinated solvents, but plans to analyze produced water for VOCs are included in the regional monitoring program (fig. 7). 


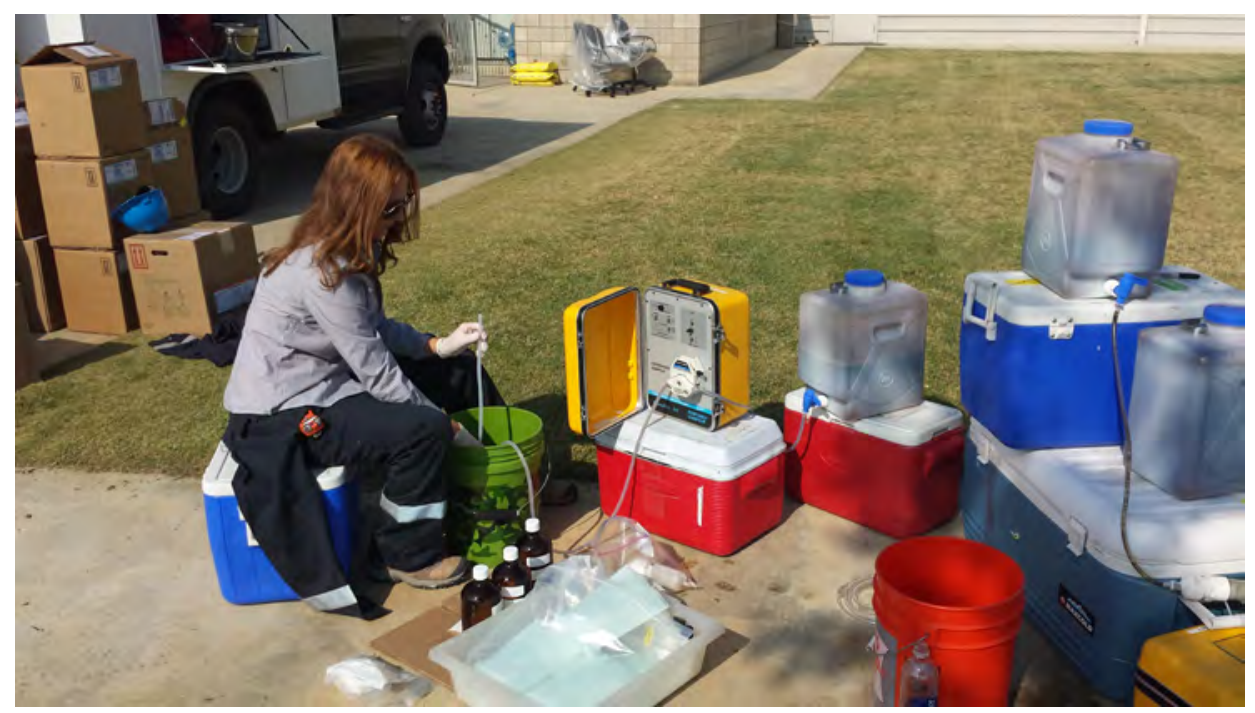

Figure 7. A U.S. Geological Survey hydrologist collecting samples of produced water in Kern County, California, for the exploratory sampling study during 2014-15.

\section{Tracers of Dissolved Organic Carbon in Oil-Field-Formation Water}

Dissolved organic carbon (DOC) in oil-field-formation water is likely to be at higher concentrations and have a different chemical composition than DOC in groundwater, given the intimate contact between the formation water and oil and gas. Thus, DOC concentrations and compositions could be useful tracers for understanding connections between aquifers and oil-field formations. The samples of produced water from oil wells in the southern San Joaquin Valley, for example, contained 130 to $209 \mathrm{mg} / \mathrm{L}$ of DOC, whereas groundwater samples from the valley only contained 0.4 to $39 \mathrm{mg} / \mathrm{L}$ (Dillon and others, 2016). Ongoing analysis of the composition of DOC in the samples of groundwater and produced water, using techniques such as 3-D fluorescence spectroscopy (Bergamaschi and others, 2005; Dahm and others, 2013), could reveal differences between the composition of DOC in groundwater and produced water that can aid in recognizing and understanding connections between aquifers and oil-field formations. Chemical characterization of DOC in groundwater and in a range of producedwater samples is planned as part of the regional monitoring program.

\section{Conclusion}

Useful tracers of the effects of oil and gas production activities on California groundwater were identified from this exploratory sampling study. Multiple tracer approaches were needed to recognize the presence of different chemicals from oil-field formations in groundwater. The data indicated that patterns of the chemicals present in groundwater derived from oil-field formations can be complex. Salts (chloride, boron, and other inorganic ions) and thermogenic methane from oil-field formations were present in some groundwater samples, whereas only salts or thermogenic methane were present in others. Hydrocarbons, such as benzene, were detected in some samples that contained modern groundwater and manufactured VOCs, and were also detected in some groundwater that appeared to be hundreds or thousands of years old and did not contain manufactured VOCs, indicating the presence of hydrocarbons both from land-surface and subsurface sources in groundwater. The study showed that thorough characterization of the chemical and isotopic composition of produced water in and between oil fields is needed to understand connections between aquifers and oil-field formations. The characterization of produced water is a component of the regional monitoring program.
Chemical, isotopic, and groundwater-age tracers examined in this study are to be incorporated into the regional monitoring program to assess the effects of oil and gas production activities on groundwater resources. Understanding the transport pathways by which chemicals from oil-field formations reached the aquifers was beyond the scope of the exploratory study, but it is important to the understanding of connections between aquifers and oil-field formations. Study of these transport pathways by using the tracers identified in this study is a component of the regional monitoring program.

\section{Acknowledgements}

This report is a product of the California Oil and Gas Regional Groundwater Monitoring Program of the California State Water Resources Control Board. We thank well owners who provided permission for collection of samples from wells. We thank the Water Replenishment District (WRD) of Southern California for extensive logistical support in sampling WRD monitoring wells in Los Angeles County.

\section{References Cited}

Avrahamov, N., Gelman, F., Yechieli, Y., Aizenshtat, Z., Nissenbaum, A., and Sivan, O., 2015, Proposed sources of methane along the Dead Sea Transform: Chemical Geology, v. 395, p. 165-175.

Bergamaschi, B.A., Kalve, E., Guenther, L., Mendez, G.O., and Belitz, K., 2005, An Assessment of Optical Properties of Dissolved Organic Material as Quantitative Source Indicators in the Santa Ana River Basin, southern California: U.S. Geological Survey Scientific Investigations Report 2005-5152, $38 \mathrm{p}$.

Blondes, M.S., Gans, K.D., Thordsen, J.J., Reidy, M.E., Thomas, B., Engle, M.A., Kharaka, Y.K., and Rowan, E.L., 2014, U.S. Geological Survey National Produced Waters Geochemical Database v2.1 (provisional): U.S. Geological Survey Web page accessed April 22, 2015, at http://energy.usgs.gov/ EnvironmentalAspects/EnvironmentalAspectsofEnergyProductionandUse/ ProducedWaters.aspx\#3822349-data. 


\section{References Cited-Continued}

California Department of Oil, Gas, and Geothermal Resources, 2014, District 4 Chemical Analyses for Fruitvale Oil Field, accessed June 29, 2016, at ftp://ftp.consrv.ca.gov/pub/oil/D4\%20 Chemical\%20Analysis/Fruitvale/.

California Department of Water Resources, 2015, Digital spatial data of water-quality data for groundwater wells, received June 5, 2015, by email; currently available on the Web at http://www.water.ca.gov/waterdatalibrary/waterquality/index.cfm/.

California State Water Resources Control Board, Division of Drinking Water, 2015, Digital spatial data of water quality data for public supply wells, accessed February 2015 at http://www. waterboards.ca.gov/drinking_water/ certlic/drinkingwater/EDTlibrary. shtml.

California State Water Resources Control Board, 2016, California regulations related to drinking water, http://www. waterboards.ca.gov/drinking_water/ certlic/drinkingwater/Lawbook.shtml.

Coleman, D.D., Risatti, J.B., and M. Schoell, 1981, Fractionation of carbon and hydrogen isotopes by methaneoxidizing bacteria: Geochimica et Cosmochimica Acta, v. 45, p. 1033-1037.

Dahm, K.G., Van Straaten, C.M., Munakata-Marr, J., and Drewes, J.E., 2013, Identifying well contamination through the use of 3-D fluorescence spectroscopy to classify coalbed methane produced water: Environmental Science \& Technology, v. 47, p. 649-656.

Davis, T.A., Kulongoski, J.T., and McMahon, P.B., 2016, Produced water chemistry data for samples from four petroleum wells, southern San Joaquin Valley, California, 2014: U.S. Geological Survey Data Release, http://dx.doi.org/10.5066/F7XG9P83.

Dillon, D.B., Davis, T.A., Landon, M.K., Land, M.T., Wright, M.T., and Kulongoski, J.T., 2016, Data from exploratory sampling of groundwater in selected oil and gas areas of coastal Los Angeles County and Kern and Kings Counties in southern San Joaquin Valley, 2014-15: California Oil, Gas, and Groundwater Project: U.S. Geological Survey Open-File Report 2016-1181, 24 p.
Engle, M.A., Reyes, F.R., Varonka, M.S., Orem, W.H., Ma, L., Ianno, A.J., Schell, T.M., Xu, P., and Carroll, K.C., 2016, Geochemistry of formation waters from the Wolfcamp and "Cline" shales: Insights into brine origin, reservoir connectivity, and fluid flow in the Permian Basin, USA: Chemical Geology, v. 425, p. 76-92.

Jackson, R.E., Gorody, A.W., Mayer, B., Roy, J.W., Ryan, M.C., and Van Stempvoort, D.R., 2013, Groundwater protection and unconventional gas extraction: The critical need for field-based hydrogeological research: Groundwater, v. 51, p. 488-510.

Jeffrey, A.W., Alimi, H.M., and Jenden, P.D., 1991, Geochemistry of Los Angeles Basin oil and gas systems: In Active Margin Basins, ed., Biddle, K.T., American Association of Petroleum Geologists: Memoir 52, p. 197-219.

Jurgens, B.C., Fram, M.S., Belitz, K., Burow, K.R., and Landon, M.K., 2010, Effects of groundwater development on uranium: Central Valley, California, USA: Groundwater, v. 48, p. 913-928.

Landon, M.K., and Belitz, K., 2012, Geogenic sources of benzene in aquifers used for public supply, California: Environmental Science \& Technology, v. 46, p. 8,689-8,697.

Martens, C.S., Albert, D.B., and Alperin, M.J., 1999, Stable isotope tracing of anaerobic methane oxidation in the gassy sediments of Eckernförde Bay, German Baltic Sea: American Journal of Science, v. 299, p. 589-610.

Michel, R.L., 1989, Tritium deposition in the continental United States, 1953-83: U.S. Geological Survey Water-Resources Investigations Report 89-4072, 46 p.

Rozanski, K., Araguás- Araguás, L., and Gonfiantini, R., 1993, Isotopic patterns in modern global precipitation: In Climate Change in Continental Isotopic Records, eds., Swart, P.K., Lohmann, K.C., McKenzie, J., and Savin, S., American Geophysical Union: Geophysical Monograph 78, p. 1-36.

Schoell, M., 1980, The hydrogen and carbon isotopic composition of methane from natural gases of various origins: Geochimica et Cosmochimica Acta, v. 44, p. 649-661.
Shelton, J.L., Pimentel, Isabel, Fram, M.S., and Belitz, Kenneth, 2008, Ground-water quality data in the Kern County subbasin study unit, 2006Results from the California GAMA Program: U.S. Geological Survey Data Series 337, 75 p.

Stumm, W., and Morgan, J.J., 1981, Aquatic Chemistry: New York, John Wiley and Sons, p. 567.

Thamke, J.N., and Smith, B.D., 2014, Delineation of brine contamination in and near the East Poplar oil field, Fort Peck Indian Reservation, northeastern Montana, 2004-09: U.S. Geological Survey Scientific Investigations Report 2014-5024, 40 p.

U.S. Geological Survey, 2016, National Water Information System-Web interface, USGS water data for California, accessed January 21, 2016, at http:// waterdata.usgs.gov/ca/nwis/.

Warner, N.R., Jackson, R.B., Darrah, T.H., Osborn, S.G., Down, A., Zhao, K., White, A., and Vengosh, A., 2012, Geochemical evidence for possible natural migration of Marcellus Formation brine to shallow aquifers in Pennsylvania: Proceedings of the National Academies of Science, v. 109, p. 11,961-11,966.

Whiticar, M.J., 1999, Carbon and hydrogen isotope systematics of bacterial formation and oxidation of methane: Chemical Geology, v. 161, p. 291-314.

Whiticar, M.J., Faber, E., and Schoell, M., 1986, Biogenic methane formation in marine and freshwater environments: $\mathrm{CO} 2$ reduction vs. acetate fermentation-Isotopic evidence: Geochimica et Cosmochimica Acta, v. 50, p. 693-709.

Zogorski, J.S., Carter, J.M., Ivahnenko, Tamara, Lapham, W.W., Moran, M.J., Rowe, B.L., Squillace, P.J., and Toccalino, P.L., 2006, The quality of our Nation's waters - Volatile organic compounds in the Nation's ground water and drinking-water supply wells: U.S. Geological Survey Circular 1292, $101 \mathrm{p}$.

For more information contact:

Director

U.S. Geological Survey

California Water Science Center

6000 J Street, Placer Hall

Sacramento, CA 95819

http://ca.wr.usgs.gov 